Article

\title{
What You Sow Is What You Reap? (Dis-)Incentives for Adaptation Intentions in Farming
}

\author{
Franca Buelow and Nicholas Cradock-Henry * (iD \\ Governance \& Policy, Manaaki Whenua Landcare Research, Lincoln 7640, New Zealand; \\ buelowf@landcareresearch.co.nz \\ * Correspondence: cradockhenryn@landcareresearch.co.nz
}

Received: 28 February 2018; Accepted: 3 April 2018; Published: 10 April 2018

\begin{abstract}
Adaptation by farmers and other land managers responsible for climate-sensitive activities is central to ensuring resilience in the face of ongoing climate variability and change. However, there remains an adaptation deficit among agricultural producers: action to reduce vulnerability to the impacts of climate change is insufficient. To motivate adaptation, diverse incentives are in place most notably through the European Union's Common Agricultural Policy which offers financial incentives to farmers. However, the effect of incentives on behaviour appears to be low. To better understand adaptation intentions, we report on the results of a survey experiment assessing framing effects on German farmers. Four framings of adaptation motifs-financial, norms, risk awareness, and technological innovation-are tested against a socio-cognitive model based on Protection Motivation Theory (PMT). According to PMT, adaptation intentions are a function of an individual's risk and coping appraisal. Results show that, contrary to assumptions of profit maximizing individuals, economic incentives trigger fewer overall change intentions. Economic rewards do act on risk perception, but are less likely to trigger coping perception, while other treatments do. As coping perception is one of two socio-cognitive reactions to climate change, financial incentive structures fail to act on about half the factors leading to adaptation intentions. These effects dependent on subgroups, farm structures, and are mediated by climate experience. To support transitions towards robust adaptation, adaptation incentives must move beyond financial framings alone, and leverage on farmers' recent experiences with adverse climate impacts, understandings of climate change, and the influence of social norms.
\end{abstract}

Keywords: survey experiment; protection motivation theory; climate change adaptation; behaviour change

\section{Introduction}

The global climate is already changing in line with modelled projections with implications for linked social-environmental systems and practices [1,2]. Agriculture is one of the most climate-exposed sectors, and agricultural producers are likely to face ever increasing challenges to maintain productivity $[3,4]$. Warming and drying, increased seasonal variability in rainfall and increasing frequency and severity of extreme weather events including drought, storms, forest fires, and rainfall extremes present significant challenges to agricultural production [5-7]. Climate change is expected to have the combined effect of reducing crop yields, increasing food insecurity and undermining traditional agricultural practices [8-10]. Additional effects relating to changes in mean climatic conditions have implications for land use, biosecurity and novel pests, and demand for water resources [11]. Furthermore, exposure to climatic conditions will not occur in isolation, rather in conjunction with other multiple, non-climatic stressors [12] including trade liberalisation [13,14]. 
Adaptation-a conscious reaction to actual or expected changes-is essential to maintaining the competitiveness and sustainability of agricultural production in the face of climate change $[15,16]$. However, shifting/changing entrenched behaviours, and promoting changes in land management practices to ensure farmers are prepared for, and adapted to anticipated changes in climatic conditions is difficult. Studies of farmers' perceptions of climate change, for example, show that they recognize changing weather trends, but do not necessarily identify them as part of a long-term trend, let alone equate them with climate change or adapt as a result $[17,18]$. Climate change effects are quite heterogeneous and involve a high degree of uncertainty, which further complicates planning. Furthermore, the effects of climate change are but one limiting factor in agricultural production and planning and their relevance depends largely on the degree of "cognitive availability" and personal affectedness by climate change events and effects [19]. Consequently, many farmers' adaptation is limited, as has been shown in recent evaluations of U.S. farming behaviour in the context of projected and current substantial losses and decreased productivity in the sector $[17,20]$.

Psychological factors have a considerable influence on adaptation decisions and actions (e.g., $[16,17,20])$, however significant gaps remain in our understanding of the ways in which farmers' experiences, concerns, and actions are linked, and may (or may not) catalyse adaptation actions. To understand why people change their behaviour with regard to climate change issues, several studies have drawn on Protection Motivation Theory (PMT) [16,21-24]. PMT builds on extensive work by Rogers [25] on protective behaviour in the medical sciences, in which individuals showed two defining socio-cognitive reactions when faced with an exterior risk, namely risk perception and coping perception. Grothmann and Patt [16] extended the original PMT framework by further compartmentalizing and diversifying the two main socio-cognitive processes for adaptation. They introduced a Model of Private Proactive Adaptation Action (MPPAA), adding three external factors to their model, all of which act on an individual's socio-cognitive perception of risks and/or coping capacities: (1) social discourse; (2) adaptation incentives; and (3) objective adaptive capacity, such as money, power, knowledge, entitlements, as well as social and institutional support [16] (p. 204). Adaptation is realized relative to the strength with which exterior factors impact on an individual's evaluation of adaptation intentions; they act as mediators to our own cognitive response to real world threats [16]. Incentives are included as enablers; however, the model neither specifies how incentives act on human perception nor does it account for heterogeneous effects that incentives may have on individuals. Such insights are essential to developing a better understanding of the effects of regulation on behaviour change intentions.

This paper aims to address knowledge gaps in the literature on adaptation behaviour by applying Grothmann and Patt's model in an experimental setting to better account for individual farmers' appetite for risk, and capacity for coping. This contributes to an empirical understanding of the measurable and alterable psychological conditions of individual-level behaviour change and provides causal explanations for their relevance, based on a survey experiment, analysing framing effects on German farmers' adaptation intentions. The study also addresses the assumed perfect rationality of individual actors who respond to the logic of gains and losses in a straightforward fashion. Farmers and land managers are currently eligible for subsidies under the European Union's Collective Agricultural Policy (CAP) designed to encourage adaptation to climate change. If farmers are indeed rational economic actors, we might expect higher levels of adaptation action than we currently see. We peer into the black box of adaptation intention to look more closely at the relationship between financial incentives and adaptation action, in order to provide new insights to policy-makers and practitioners working to enhance resilience in agriculture.

\section{Materials and Methods}

The primary evaluation tool was a survey questionnaire. The survey design —-based on framing theory - enabled us to draw inferences relating to attitudes and behaviour from survey data [26] and to help compare and assess the distinctive, causal effects of treatments. A prime motivation for this type of research is to determine the effects of different communications strategies of groups of individuals. 
Framing experiments emphasize certain characteristics of communication affecting attitudes toward an object (e.g., policy) "by increasing the weight given to a subset of relevant considerations" [27]. Framing is considered "an unavoidable reality of the [science] communication process" [27,28] (p. 1771) as mental pictures, e.g., frames, shape the way we see the world [29]. One can go so far as to say that all information is (intentionally or unintentionally) framed by the context within which it is presented [30]. Respondents do not enter surveys as blank slates [31] (p. 109). In other words, survey experiments can be seen as the endeavour to understand pre-treatment, any previous conditioning individuals experience in their day to day lives [31] (p. 110). Building on this, the search for the "right" baseline of a framing experiment often results in a comparison of alternative communication strategies rather than comparison between treatment and no-treatment groups [32] (p. 310). This was also applied in this study as it is plausible to assume that (policy) incentives can be thought of as different-and competing-frames that shape the everyday life of a farmer. The element of causality implicit in the research design accounts for confounding variables and facilitates the assessment of conditioning factors and their relative effects.

To determine which incentives resonate most with farmers, four frames based on motivations for behaviour change were tested: financial matters, societal acceptance, risk information, and access to technology [33-40]. The original survey was distributed in German and is provided in the Appendix A. The relevance of incentives to the four treatment groups is predicted by the Model of Private Proactive Adaptation Action [16]. Furthermore, the effects of the four frames are compared and analysed to assess which line of reasoning corresponds best with farmers. Gaining insight into the factors that explain adaptation intentions and actions can inform targeted communications to facilitate adaptation to external shocks and stressors [24,41]. This implicitly assumes that successful adaptation is a function of both individual willingness to adapt and choice architecture that encourages adaptive actions [39]. To explore this in more detail, we test the following hypothesis: financial incentives trigger less pronounced socio-cognitive reaction in farmers than other frames that rely on different motivations for behaviour change.

\subsection{Frames Tested in This Study}

Four frames were tested in this study. The baseline (Frame 1) was based on the European Union's Common Agricultural Policy (CAP), a system of agricultural subsidies and other programmes designed to incentivize good land management practices. For example, financial incentives or penalties encourage people to avoid losses, through climate-friendly farming [34-36]. Rewards and penalties are thus the status quo for survey participants, and the CAP's financial incentives for German farmers' farming decisions act as a basis for comparison with other frames.

Financial incentives are one way of approaching individuals' decisions in interdependent situations characterised by collective action problems. Such situations occur when the maximisation of short-term self-interests has an overall negative effect on public/common interests (e.g., [42]).

The CAP's incentives are based on a rational-actor-model, which assumes that we are self-interested, short term maximisers [42] (p. 2). However, this model of decision-making has been challenged in the literature and consequently broadened to also include "irrational" choices (e.g., $[39,43])$. When assessed with a more complex theory of behaviour, the "redemptive power of rewards" shows its flaws: Financial incentives achieve only temporary compliance, because extrinsic motivators do not alter attitudes that underlie behaviours, habits and norms [44]. As a result, financial penalties become less efficient. People work around them to avoid the need to change [36], and, furthermore, financial rewards reduce the intrinsic motivation to act as individuals start to expect rewards for their actions after receiving the first monetary incentive [43,44], which decreases the likelihood of voluntary change.

To explore what resonates with farmers change intentions, three alternative frames to motivate and incentivize adaptation intentions and actions were tested in this study: norms, risk communication and the more controversial technological fix. To a large extent, people select green options that imply 
their idealized self-conceptions in accordance with what they want to signal to others (so-called expressive considerations [39]). Frame 2 was designed to capture an individual's need to be seen as moral in the sense that she contributes to the sustainable development of society. Societal norms are important for a broader acceptance of climate adaptation [39]. This is because humans are deeply concerned with being seen as interpersonally warm, competent and moral [38].

Frame 3 related to risk communication, pointing to the negative effects of climate change in terms of production losses, and subsequent effects on future generations and the growing population. Kachi et al. [40], for example, found that individuals who worry about the risks of climate change are generally more supportive of climate policies. While risk communication alone does not necessarily result in individual adaptive action, framing risks in a way that implies the (social) effects of (in)action, increases the likelihood of change [38] (p. 3). In an experiment on communicating climate risks, Bolsen et al. [27] found that an emphasis on both "individual responsibility and collective environmental benefits can stimulate collective action" [27] (p. 24). This builds on findings concerning the norm-activation-model (NAM [33]) as well as the value-belief-norm theory of environmentalism (VBN theory [34]), which both have explained behavioural change intentions in other research designs [37]. More specifically, highlighting the coupled relationship between adaptation and scientific and economic progress can incentivise adaptive action.

Finally, Frame 4 showcased the benefits of technological innovation. Technology plays a critical role in adaptation (e.g., $[14,45,46])$. Technological advances in farming, including new machinery, management practices, and breeding, have all led to higher outputs. Innovative technology implies changes in routine and challenges assumptions related to accepted management practices. Users of new technologies need to understand, buy and use them to achieve noticeable effects and transitions to new norms with the aid of innovative tools and machinery [37]. Incorporating a human dimension to technology development and implementation enhances the fit within the human-technology-environment nexus $[47,48]$. Trust in technology is the first step of application, and the use of such technologies precedes societal support and acceptance. In the context of PMT, the implications are that farmers become complacent if they rely exclusively on technological fixes to cope with the effects of climate change.

\subsection{Survey Items and Logic}

Socio-economic and cognitive variables are most widely used to explain and better understand adaptation intention and behaviour [24]. They provide insight into a range of factors including response- and self-efficacy, response costs, intrinsic and extrinsic rewards of behaviour change, and relative vulnerability $[16,21-24,41]$. This demographic and contextual information is collected via the survey instrument, including farm size, location, and ownership, farmer roles and responsibilities, levels of technical and informational preparedness for climate variability and extremes, and implementation of farming measures that are part of the European Union's Common Agricultural Policy (CAP). Specific prompts to CAP measures that have a positive effect on agricultural adaptation to climate change [48] were included in the survey. The survey also included questions relating to interest and knowledge of climate change, individual risk perception, and trusted sources of information. To explore the mediating effect on adaptation intentions and behaviour that has been discovered in other research projects $[20,24]$, questions on experience with extreme events were included, the results of which are then modelled to represent the interaction effect using cell means [49].

Survey respondents' adaptation intention was tested in a set of 16 statements that had to be evaluated after reading the framing treatment, with participants' approval ratings ranging from "fully agree" (5) to "do not agree" (1). The statements were chosen in accordance with Grothmann and Patt's research design [16] as well as Koerth and co-workers' PMT items [24] (p. 901). Table 1 gives an overview on the dependent variables (cf. Appendix A for simple mean effects of all 16 dependent variables, Table A1). 
Table 1. DV here.

\begin{tabular}{ccc}
\hline DV Number & DV Name & Statement \\
\hline 1 & OV_thinkCC & It is important to think about climate change effects and impacts. \\
2 & OV_CCnoRisk & Adaptation to climate change is not important, as climate change risks are not increasing. \\
3 & OV_CCnoAdapt & There is no reason to adapt to climate change. \\
4 & OV_CCrisk & Climate change is a serious risk to humankind. \\
5 & CC_longtermEffect & Climate change has long-term negative effects on agriculture. \\
6 & OV_CCnow & Climate change is happening right now. \\
7 & OV_CCimplPersonal & My life is affected by climatic changes and variability. \\
8 & OV_CCBadFuture & The impact of climate change on agriculture will get worse. \\
9 & CC_AdaptFarming & Individuals can do something to adapt to climate change. \\
10 & OV_PrevRisk & I am capable of meeting climate change challenges. \\
11 & OV_AdaptPersSafe & Preventive measures reduce the costs associated with climate change. \\
12 & Ov_AdaptnoEffect & Adaptation to climate change increases my personal safety. \\
13 & OV-AdaptCost & Adaptation to climate change has no effect on my farming. \\
14 & OV_AdaptTimeNeed & It is less costly to adapt than to pay for damages. \\
15 & OV_Spending & Adaptation to climate change takes too much time. \\
16 & & I would rather spend money on something other than climate change adaptation. \\
\hline
\end{tabular}

A linear regression model was used to test farmers' relative adaptation intention, analysing the variance of approval to statements between treatment groups, determining their relative risk and coping appraisal after having reading through (i.e., being treated with) the frames. Control variables, such as the experience of an extreme weather event, experience of different weather trends in the past years (covering rain, drought, heat, storm, snow, hail, and flood), risk perception, and farming type (conventional, organic or bio-dynamic), were added across all OLS analyses.

\subsection{Sampling and Distribution}

The survey was distributed online via email and included a web link. Over one hundred farmers $(n=102)$ participated in the survey; 85 fully completed the survey. This $(n=85)$ provided the data for analysis. The survey was disseminated between October 2014 and October 2015 via farmers' networks as well as one of the biggest insurance company's mailing lists. A cover letter was attached to the survey, and provided background information on the study, but did not disclose the rationale for the experiment's design. After clicking the link, respondents were randomly assigned to one of four versions of the survey versions. The treatment was introduced as a separate survey section in the form of a short scenario, 5-8 sentences long. Participants were evenly distributed across treatment groups (Frame 1: 22; Frame 2: 20; Frame 3: 21; Frame 4: 22), and did not differ significantly with regard to observable characteristics, indicating efficient randomization. Treatment groups did not differ significantly in their composition. The analysis of exogenous factors that could systematically mediate subjects' responses revealed no results that would challenge the effect of frames on the dependent variables (cf. Table 2).

This excluded any mediating effects and allowed for confidence concerning experimental effects [50]. The external validity of survey experiments is the subject of some debate [50,51]. One threat to external validity is restricted subject participation [50] (p. 36). To ensure variation, different networks and groups, representing diverging takes on agricultural production and values concerning resource-governance were approached over a period of one year. However, the data discussed here and the results from the survey experiment were based on a relatively small convenience sample. As Mullinix et al. [51] showed, convenience samples—including the sample in this project-produce considerably similar results as population based, nationally representative samples. They concluded that convenience samples can play a fruitful role as research agendas progress [51] (p. 111). As such, the study reported on here provided a basis for further, more in-depth analysis of framing effects on adaptation intentions in the agricultural sector. Such studies might enhance the robustness and scalability of our findings. 
Table 2. Randomisation Control.

\begin{tabular}{cc}
\hline Variable & Frame \\
\hline Prev_Extreme_Weather & $0.169(0.291)$ \\
Risk_indiv & $-0.024(0.153)$ \\
Farming_Typeconventional agriculture & $0.127(0.587)$ \\
Farming_Typeorganic farming & $0.321(0.622)$ \\
Gender & $-0.179(0.374)$ \\
Age & $0.018^{*}(0.009)$ \\
Info_CC & $0.155(0.168)$ \\
Network_Active & $0.167(0.171)$ \\
Constant & $-33.909 *(18.362)$ \\
N & 84 \\
R-squared & 0.114 \\
Adj. R-squared & 0.020 \\
Residual Std. Error & $1.135(\mathrm{df}=75)$ \\
F Statistic & $1.208(\mathrm{df}=8 ; 75)$ \\
$\quad$ *** $p<0.01 * * *<0.05 * *<0.1$ &
\end{tabular}

\section{Results}

The majority of survey respondents are male (79\%) with a median age of 43 years. Most respondents are farm owners $(60 \%$, as opposed to tenants). The average number of employees on each farm is 6.9. Survey respondents work between 39 and $\geq 40$ hours per week (83\%). Most of the people who participated live in northern Germany, in Schleswig-Holstein (52\%), the second biggest group are from southern Germany, Baden-Wurttemberg (16\%), and Rhineland Palatinate (7\%). Most of the participants engage in conventional agriculture (74\%) as opposed to $20 \%$ organic and $6 \%$ biodynamic agriculture. Farmed areas range in size from between 60 and 200 ha (cf. Appendix A for an overview of all survey items (mean, standard deviation, minimum and maximum values).

Respondents' reactions to two statements are discussed here to account for two of 16 facets of risk and coping appraisal: (1) "Climate change is a serious risk to me" to account for risk perception; and (2) "My farming is adapted to climate change" to reflect on respondents' self-efficacy. We have chosen to discuss those two as they show the most pronounced results (cf. Appendix A for an overview on effects on all variables in Table A1). Previous experience with an extreme event has a demonstrated effect on the treatment group's assessment of the degree to which they consider climate change a risk and how they assess their ability to cope with climate change. Furthermore, the framing effect differed in relation to the type of farm. Biodynamic and organic farmers, for example, show higher degrees of agreement towards the statement. Heterogeneity in the data is a result of the differences across sub-groups and can be explained by varying degree of adaptive capacity according to farming types. As the interaction of means shows, different farming types result in different effects.

The treatment groups respond differently to the statement "Climate change is a serious risk to

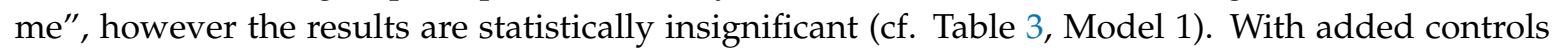
(region, farming type and individual risk prevalence) the overall explanatory power of the model is considerably improved (cf. Table 3, Model 2). Organic farming turns out to be negative and highly significant $(p<0.05)$, probably explained by the already relatively risk approved farming type. Here, experience with an extreme event turns out to be positive and highly significant $(p<0.01)$. Experience acts as a moderator on one's ability to assess climate risks and the respond to climate change impacts [20,24]. When modelling an interaction effect between frames and previous experience of an extreme weather event, organic farming remains negative and significant (cf. Table 3 , Model 3). The interaction reveals that participants respond comparatively negative to the statement

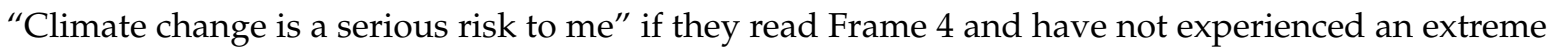
event (cf. Figure 1). This suggests that a technology framing of adaptation to climate change reduces risk appraisal. 
Table 3. Model Results for DV "Climate change is a serious risk to me".

\begin{tabular}{cccc}
\hline & Simple Effect & Effect Controls & Interaction Effect \\
\cline { 2 - 4 } & Model 1 & Model 2 & Model 3 \\
\hline Frame 2 & $0.283(0.362)$ & $0.153(0.319)$ & $-0.047(0.493)$ \\
Frame 3 & $-0.017(0.362)$ & $-0.060(0.314)$ & $-0.141(0.490)$ \\
Frame 4 & $0.018(0.367)$ & $-0.120(0.320)$ & $-1.323^{* *}(0.610)$ \\
CC Experience & & $1.225^{* * *}(0.252)$ & $0.784^{*}(0.454)$ \\
Conventional Agriculture & & $-0.662(0.488)$ & $-0.666(0.480)$ \\
Organic Farming & & $-1.202^{* *}(0.546)$ & $-1.124^{* *}(0.539)$ \\
Risk_indiv & & $-0.169(0.140)$ & $-0.125(0.139)$ \\
Frame 2 CC Experience & & $0.356(0.632)$ \\
Frame 3 $\times$ CC Experience & & $0.144(0.629)$ \\
Frame 4 CC Experience & $3.667 * * *(0.253)$ & $4.124 * *(0.740)$ & $4.603^{* * *}(0.716)$ \\
Constant & 80 & 80 & $8.260^{* * *}(0.753)$ \\
N & 0.012 & 0.306 & 80 \\
R-squared & -0.027 & 0.239 & 0.360 \\
Adj. R-squared & $1.160(\mathrm{df}=76)$ & $0.999(\mathrm{df}=72)$ & 0.267 \\
Residual Std. Error & $0.301(\mathrm{df}=3 ; 76)$ & $4.542^{* * *}(\mathrm{df}=7 ; 72)$ & $3.877^{* * *}(\mathrm{df}=10 ; 69)$ \\
F Statistic & $* * * p 0.01 ; * *<0.05 ; *<0.1$. &
\end{tabular}

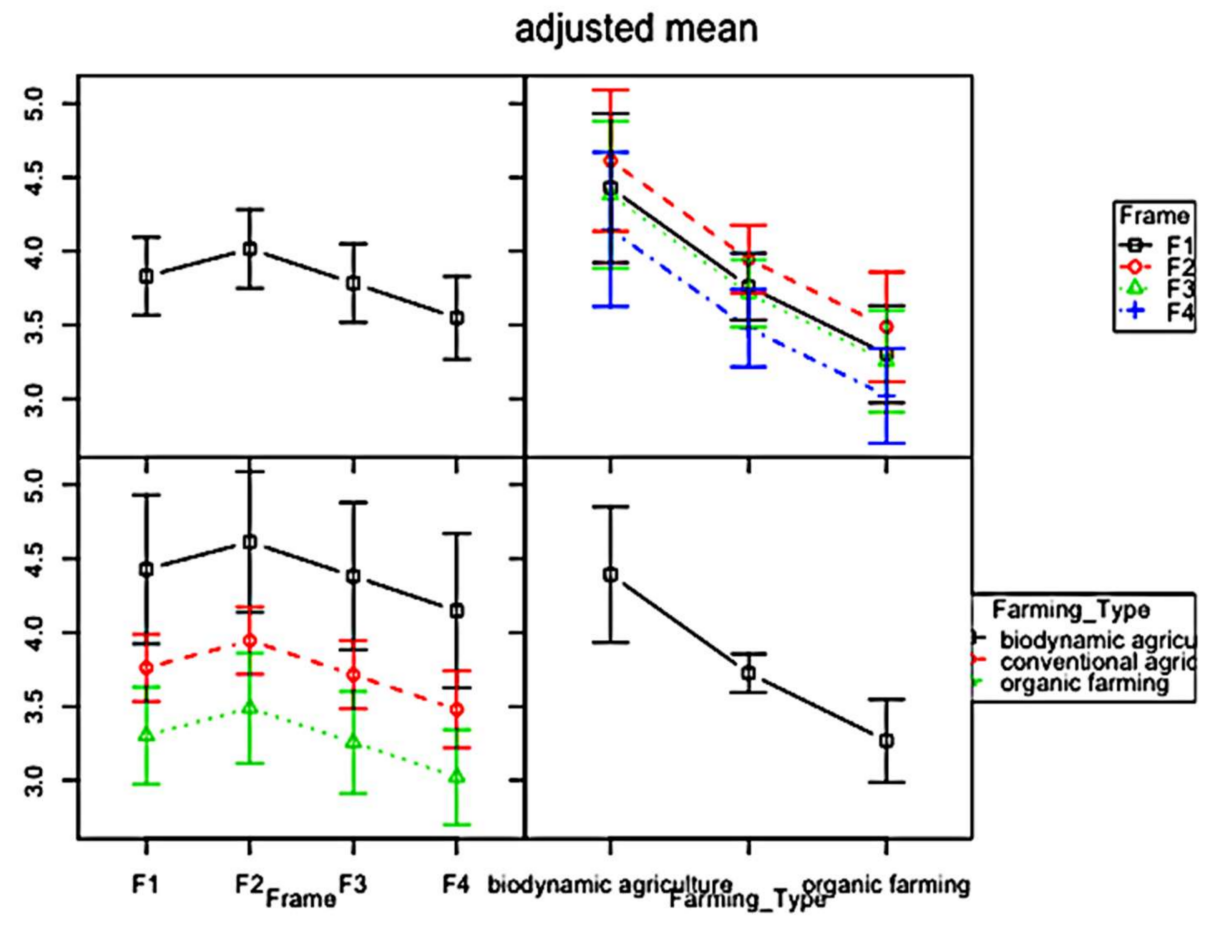

Figure 1. Interaction effects DV "Climate change is a serious risk to me".

The treatment groups also respond differently to the statement "My farming is adapted to climate change". Frames 3 and 4 are positive and significant $(p<0.05)$, relative to the baseline group (cf. Table 4 , Model 1). These treatment groups therefore view regard their agricultural practices as better adapted than the baseline group. This effect is reduced with added controls and only Treatment Group 4 is marginally significant $(p<0.1)$ compared to baseline. The control variables added once again include individual experience with extremes, risk perception, and farming type. Following this, Model 3 shows the interaction effect between frames and experience of an extreme weather event. This improves 
the model specification and changes the framing effects. As shown in Figure 2, experience with an extreme weather event is relevant to farmers' self-assessment concerning farm-level adaptation and preparedness. As long as they have experience with an extreme weather event, Treatment Group 3 (community building frame) considers their farming practices to be more adaptive than the baseline group. In brief, individuals may be more likely to assess their self-efficacy positively having been through (and coped with) an extreme event.

Table 4. Model Results for DV "My farming is adapted to climate change".

\begin{tabular}{|c|c|c|c|}
\hline & Simple Effect & Effect Controls & Interaction Effect \\
\hline & Model 1 & Model 2 & Model 3 \\
\hline Frame 2 & $0.495(0.317)$ & $0.465(0.319)$ & $0.948 * *(0.457)$ \\
\hline Frame 3 & $0.545 *(0.317)$ & $0.522(0.315)$ & $-0.392(0.455)$ \\
\hline Frame 4 & $0.674^{* *}(0.321)$ & $0.597 *(0.320)$ & $1.012 *(0.566)$ \\
\hline CC Experience & & $0.227(0.252)$ & $0.140(0.422)$ \\
\hline Conventional & & $-0.780(0.489)$ & $-0.823 *(0.445)$ \\
\hline Organic & & $-0.458(0.546)$ & $-0.592(0.500)$ \\
\hline Risk_indiv & & $-0.152(0.140)$ & $-0.139(0.129)$ \\
\hline Frame $2 \times$ CC Experience & & & $-0.827(0.587)$ \\
\hline Frame $3 \times$ CC Experience & & & $1.520 * *(0.583)$ \\
\hline Frame $4 \times$ CC Experience & & & $-0.493(0.664)$ \\
\hline Constant & $2.905^{* * *}(0.221)$ & $3.881^{* * *}(0.741)$ & $3.954 * * *(0.699)$ \\
\hline $\mathrm{N}$ & 80 & 80 & 80 \\
\hline R-squared & 0.064 & 0.139 & 0.317 \\
\hline Adj. R-squared & 0.027 & 0.056 & 0.218 \\
\hline Residual Std. Error & $1.014(\mathrm{df}=76)$ & $0.999(\mathrm{df}=72)$ & $0.909(\mathrm{df}=69)$ \\
\hline F Statistic & $1.736(\mathrm{df}=3 ; 76)$ & $1.667(\mathrm{df}=7 ; 72)$ & $3.204^{* * *}(\mathrm{df}=10 ; 69)$ \\
\hline
\end{tabular}

\section{adjusted mean}

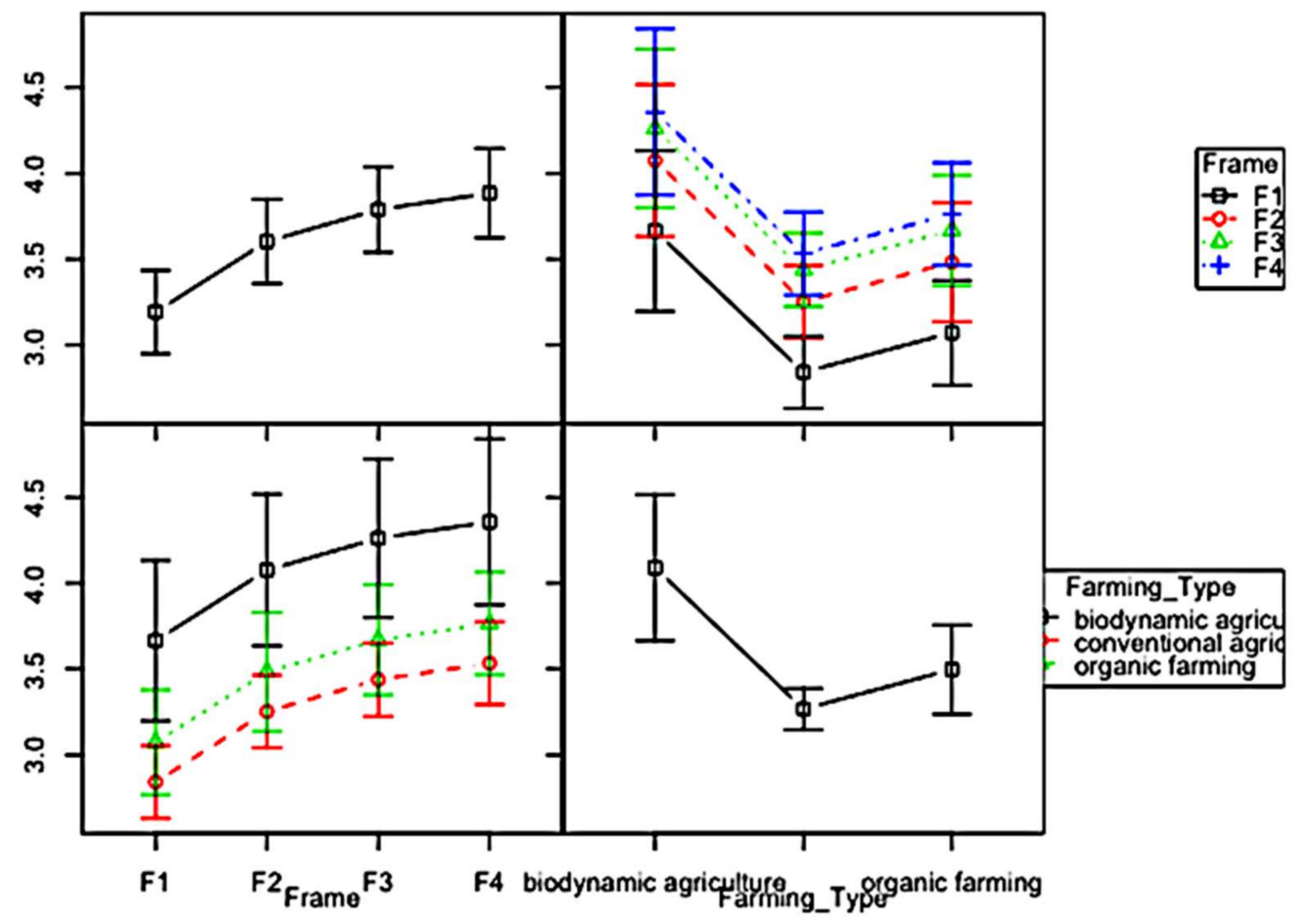

Figure 2. Interaction effects DV "My farming is adapted to climate change". 


\section{Discussion}

PMT has been successfully applied and evaluated as a valuable, viable model for understanding individual and community interventions in both medical sciences and work on climate change and individual choice of action [23,41]. In general, coping variables show slightly stronger relations with adaptation intentions than threat appraisal [40]. This relationship is also apparent in the sample analyzed here. Results also make clear that psychological factors have a considerable influence on adaptation decision making and behaviour (e.g., $[16,17,20,38,40])$ and should be considered as equally important as structural barriers to change.

While the complexity underlying decision making cannot be disregarded, there are several factors that can be discussed as generalizable, comparable trends between individual attitudes, values and subsequent actions directed towards adaptation. The model applied here accounts for such factors by looking at socio-economic and cognitive variables, social setting, and more specifically at incentives. Treatment effects in this sample show that incentives do not automatically act as enablers that trigger an adaptive response; rather the direction and power of incentives on socio-cognitive processes in farmers is highly dependent on farming contexts. Furthermore, certain conditioning factors, such as previous experience of an extreme weather event, lead farmers to different adaptation intentions [20]. Experience with extreme events mediates the socio-cognitive prevalence to form adaptation intentions. In this context, the decision to adapt is a positive function of severity of a risk, perception of vulnerability as well as the belief that one has the ability to perform a coping response and that the benefits of this coping response will outweigh the costs of the specific activity. This is particularly true of the latter; viz. the variables that account for an individual's coping appraisal, e.g., self-efficacy and response efficacy, were strongly related with an intention to adapt when emphasis was on both individual responsibility and collective environmental benefits. Part of this response can certainly be attributed to biases, however, as this is an experimental setting, it suggests a causal mechanism between: (a) realising that one is capable of making a difference; and (b) the perception of individual responsibility to act for the individual as well as public good is a desired action. Drawing on the outcomes of this research, it can be said that financial incentive structures-the status quo of environmental and climate change incentives-act on risk appraisal but have only a limited positive effect on coping appraisal. This corresponds with findings elsewhere (e.g., [24], [27] (p. 24)). In practical terms, it is less likely that policy incentives stimulate adaptation intentions and underscores the potential benefits of a redesign of current governance mechanisms for farming. Finally, the insight into communication of technological innovation and its negative effects in risk appraisal suggests that trust in technological fixes might lower adaptation intentions. Proposed geoengineering solutions have been criticised on similar grounds and are discussed in more detail elsewhere [52].

\section{Conclusions}

Changing climate conditions present a significant challenge for agricultural producers. Despite European Union CAP financial incentives intended to encourage adaptation actions, there remains a gap between what we know we should do, and what is actually happening on the ground. To address this adaptation deficit among farmers and land managers, the results of our study show that financial incentives alone are insufficient for catalysing adaptation from intention to action.

The PMT model provides a starting point for evaluating tendencies and trends in farming communities, but the results of the experiment show the need to further our understanding of the relationship between adaptation intention, decision and action. The dynamics between conditioning and mediating factors that have an impact on adaptation intentions is a first step in this direction and can help inform discussions on targeted policy design and communication. Limitations of the current study -including its explanatory power-are a function of the small sample size, and easily remedied. Additional studies, for example, could compare diverse regional backgrounds, work with farmer focus groups to discuss the appeal of specific policy measures, or follow a vignette study design to test different policy framings against each other, and develop appropriate and effective strategies 
for adaptation communications. To analyse the relevance of incentives for behaviour over time, time panel data could be included that tests the effects of interventions in specific settings.

In closing, incentives must move beyond financial framings alone. Most farmers already have experience with adverse climate impacts and have developed strategies for mitigating the short-term effects of day-to-weather $[3,7,10]$. Those experiences can be capitalised on to reframe adaptation to longer-term changes in climate. Social norms can also play a significant role in changing behaviour particularly among like groups [53]. New ways of communicating climate change information to meet farmers' information needs, providing salient, legitimate and credible science would encourage adaptation through better understanding of impacts and implications [54]. Together, broadening our view not only of individual decision-makers' motivations, but of the ways in which incentives are formalised in policy can support more resilient futures for agriculture.

Acknowledgments: The authors are thankful for comments from two anonymous reviewers and the editor of this journal. Previous versions of this article have received comments and suggestions from Christian Martin, Tim Kaiser, Marcel Dirsus and David Bencek. Financial support for publication was generously provided by Manaaki Whenua Landcare Research.

Author Contributions: The research was designed, performed and analysed by Franca Buelow who also prepared the first draft. Franca Buelow and Nicholas Cradock-Henry revised and rewrote subsequent versions. All authors read and approved the final manuscript.

Conflicts of Interest: The authors declare no conflict of interest.

\section{Appendix A}

The survey was distributed in German. The original wording of the frames is as follows:

1. DE: Neben der Sicherung des landwirtschaftlichen Einkommens ist es das Ziel der neuesten Agrarreform, eine Anpassung an den Klimawandel zu ermöglichen. Es macht Sinn, wenn die Europäische Union mit Subventionen auf Veränderungen des Klimas reagiert. Denn wenn ich meine Produktionsweise verändern soll, dann muss ich dafür auch eine entsprechende Bezahlung erhalten. EN: Besides providing a secure source of income the latest Common Agricultural Policy reforms aim to enable climate change adaptation. It makes sense for the European Union to respond to and act against climate change by implementing subsidies. If I am to change my production, I have to be paid to do so.

2. DE: Aus Umfragen geht hervor, dass es für immer mehr Menschen in Deutschland wichtig ist, klimafreundlich zu leben. Dafür verändern wir alle schrittweise unser Verhalten und arbeiten gemeinsam einer nachhaltigeren Lebensart entgegen. Das ist insbesondere deshalb wichtig, weil wir die Folgen des Klimawandels verringern können, wenn alle an einem Strang ziehen. Ich fühle mich in einer Gesellschaft wohl, in der alle gemeinsam für die gute Sache Veränderungen erwirken. So kann Klimawandel weniger Schaden anrichten. EN: Studies have shown that it is increasingly important for Germans to live in an environmentally friendly way. To do this, we all change our behaviour bit by bit and work towards a more sustainable lifestyle. This is important, because we can limit the effects of climate change if we all work together. I feel at home in a society where we collaborate for a worthy cause and try to bring about change. This way, climate change may result in less damage.

3. DE: Zukünftige Generationen sind mit den Folgen des Klimawandels konfrontiert. Schon heute ist die landwirtschaftliche Produktion durch Klimaveränderung beeinflusst. Die Forschung zeigt, dass der Klimawandel die Landwirtschaft so stark verändert, dass Erträge sinken. Für die wachsende Weltbevölkerung muss zudem immer mehr Nahrung produziert werden. Wenn wir heute etwas verändern, sichern wir die zukünftige Versorgung mit Nahrungsmitteln. Darüber hinaus gewährleistet eine Anpassung an den Klimawandel den stabilen Erwerb von Landwirten. EN: Future generations will face most of the consequences of climate change. However, today's agricultural production is already being affected by climate change. Studies show climate change can lead to lower profitability and reduced yields. However, for a growing population we 
have to provide more food. If we change something today, we can provide future food security. Furthermore, adaptation to climate change can ensure stable profitability.

4. DE: Alles ändert sich. Ich weiß, dass ständig neue Maschinen entwickelt werden, die mir das Leben einfacher und angenehmer machen können. Wenn ich heute anfange, in technologische Innovation zu investieren, ist das ein Vorteil für meinen Anbau. Bestimmt kann man auf diesem Wege bessere Erträge erwirtschaften und gleichzeitig auf das Klima achten. EN: Everything is in flux. I know that new machinery is constantly being developed that can make my life easier. Investing in technological innovation today is beneficial for my farming practices. Surely, this is a way of both achieving is higher yields and being sensitive to climate change.

Table A1. Overview of all Variables.

\begin{tabular}{|c|c|c|c|c|c|}
\hline Statistic & $\mathbf{N}$ & Mean & St. Dev. & Min & $\operatorname{Max}$ \\
\hline Age & 85 & $2,054.482$ & 751.479 & 1916 & 8900 \\
\hline Gender & 84 & 0.155 & 0.364 & 0 & 1 \\
\hline No_onfarm & 83 & 6.916 & 23.293 & 1 & 200 \\
\hline No_People_Sale & 84 & 3.488 & 15.112 & 1 & 140 \\
\hline No_People_Farming & 82 & 1.707 & 0.923 & 1 & 5 \\
\hline No_People_Innovation & 82 & 2.341 & 2.267 & 0 & 20 \\
\hline Work_Time & 83 & 3.819 & 0.735 & 1 & 5 \\
\hline Owner & 85 & 0.576 & 0.822 & 0 & 2 \\
\hline Region & 85 & 4.294 & 3.891 & 1 & 14 \\
\hline Average_No_Crops & 83 & 5.675 & 8.261 & 0 & 60 \\
\hline Use_of_Farmadvice & 85 & 2.624 & 1.058 & 1 & 5 \\
\hline Info_CC & 85 & 3.576 & 0.792 & 2 & 5 \\
\hline Network_Active & 85 & 2.259 & 0.888 & 1 & 4 \\
\hline Imp_PolReg & 85 & 3.129 & 1.193 & 1 & 5 \\
\hline Imp_Ecopactise & 85 & 4.082 & 0.954 & 1 & 5 \\
\hline Imp_Weatherinfo & 85 & 4.518 & 0.781 & 1 & 5 \\
\hline Imp_Subsidies_Sustainability & 85 & 3.506 & 1.231 & 1 & 5 \\
\hline Imp_Invest_CCinfrastruc & 85 & 3.624 & 1.012 & 1 & 5 \\
\hline Imp_Tech_Innovate & 85 & 3.718 & 0.934 & 1 & 5 \\
\hline Imp_Info_CC & 85 & 3.600 & 0.966 & 1 & 5 \\
\hline Crop_Rotation & 85 & 0.965 & 0.763 & 0 & 2 \\
\hline Grassland & 85 & 1.000 & 0.802 & 0 & 2 \\
\hline Crop_Diversity & 85 & 0.812 & 0.809 & 0 & 2 \\
\hline Insurance_CC & 85 & 0.129 & 0.431 & 0 & 2 \\
\hline Insurance_Seeds & 85 & 0.176 & 0.492 & 0 & 2 \\
\hline Improve_Irrigation & 85 & 0.271 & 0.585 & 0 & 2 \\
\hline Move_Cropland & 85 & 0.224 & 0.564 & 0 & 2 \\
\hline Frost_Protection & 85 & 0.118 & 0.391 & 0 & 2 \\
\hline Int_Pesticide & 85 & 0.412 & 0.623 & 0 & 2 \\
\hline Risk_indiv & 85 & 2.694 & 0.873 & 1 & 5 \\
\hline Trust_Church & 85 & 2.435 & 1.139 & 1 & 5 \\
\hline Trust_Fedgov & 85 & 2.447 & 0.970 & 1 & 5 \\
\hline Tust_LocalPolitics & 84 & 2.750 & 1.028 & 1 & 5 \\
\hline Trust_EU & 84 & 2.250 & 0.930 & 1 & 5 \\
\hline Trust_Police & 85 & 3.341 & 0.958 & 1 & 5 \\
\hline Trust_Friends & 84 & 4.238 & 0.801 & 1 & 5 \\
\hline Trust_Strangers & 85 & 2.529 & 0.971 & 1 & 5 \\
\hline Trust_Neighbors & 85 & 3.412 & 0.930 & 1 & 5 \\
\hline Trust_Colleagues & 84 & 3.512 & 1.000 & 1 & 5 \\
\hline Trust_Media & 84 & 2.226 & 0.961 & 1 & 5 \\
\hline Prev_Extreme_Weather & 85 & 0.647 & 0.481 & 0 & 1 \\
\hline Prep_Tech & 84 & 2.738 & 1.077 & 1 & 5 \\
\hline
\end{tabular}


Table A1. Cont.

\begin{tabular}{cccccc}
\hline Statistic & N & Mean & St. Dev. & Min & Max \\
\hline Prep_Financial & 85 & 2.729 & 1.117 & 1 & 5 \\
Occ_Flood & 84 & 0.345 & 0.478 & 0 & 1 \\
Occ_Drought & 85 & 0.671 & 0.473 & 0 & 1 \\
Occ_Snow & 84 & 0.119 & 0.326 & 0 & 1 \\
Occ_Hail & 83 & 0.217 & 0.415 & 0 & 1 \\
Occ_Storm & 85 & 0.600 & 0.493 & 0 & 1 \\
Occ_Rain & 85 & 0.753 & 0.434 & 0 & 1 \\
Occ_Heat & 85 & 0.588 & 0.495 & 0 & 1 \\
OV_thinkCC & 80 & 4.475 & 0.811 & 2 & 5 \\
OV_CCnoRisk & 80 & 2.050 & 1.135 & 1 & 5 \\
OV_CCnoAdapt & 80 & 2.438 & 1.146 & 1 & 5 \\
OV_CCrisk & 80 & 3.737 & 1.145 & 1 & 5 \\
CC_longtermEffect & 80 & 4.050 & 1.018 & 1 & 5 \\
OV_CCnow & 80 & 4.150 & 1.032 & 1 & 5 \\
OV_CCimplPersonal & 80 & 3.913 & 1.021 & 1 & 5 \\
OV_CCBadFuture & 80 & 4.075 & 0.911 & 2 & 5 \\
OV_AdaptSingle & 80 & 3.413 & 1.299 & 1 & 5 \\
CC_AdaptFarming & 80 & 3.325 & 1.028 & 1 & 5 \\
OV_PrevRisk & 80 & 3.875 & 0.933 & 2 & 5 \\
OV_AdaptPersSafe & 80 & 3.450 & 1.005 & 1 & 5 \\
OV_AdaptnoEffect & 80 & 3.013 & 1.153 & 1 & 5 \\
OV_AdaptCosts & 80 & 3.925 & 0.991 & 1 & 5 \\
OV_AdaptTimeNeed & 80 & 2.450 & 1.135 & 1 & 5 \\
OV_Spending & 80 & 2.638 & 1.183 & 1 & 5 \\
Frame_num & 85 & 2.506 & 1.140 & 1 & 4 \\
\hline
\end{tabular}

\section{References}

1. Rahmstorf, S.; Foster, G.; Cazenave, A. Comparing climate projections to observations up to. Environ. Res. Lett. 2012, 7, 044035. [CrossRef]

2. Dai, A. Increasing drought under global warming in observations and models. Nat. Clim. Chang. 2013, 3, 52-58. [CrossRef]

3. Cradock-Henry, N.A. New Zealand kiwifruit growers' vulnerability to climate and other stressors. Reg. Environ. Chang. 2017, 17, 245-259. [CrossRef]

4. Pant, K.P. Effects of agriculture on climate change: A cross country study of factors affecting carbon emission. J. Agric. Environ. 2009, 9, 84-102. [CrossRef]

5. Rickards, L.; Howden, S.M. Transformational adaptation: Agriculture and climate change. Crop Pasture Sci. 2012, 63, 240-250. [CrossRef]

6. Harrington, L.J.; Rosier, S.; Dean, S.M.; Stuart, S.; Scahill, A. The role of anthropogenic climate change in the 2013 drought over North Island, New Zealand. Bull. Am. Meteorol. Soc. 2014, 95, S45-S48.

7. Harvey, C.A.; Rakotobe, Z.L.; Rao, N.S.; Dave, R.; Razafimahatratra, H.; Rabarijohn, R.H.; Rajaofara, H.; MacKinnon, J.L. Extreme vulnerability of smallholder farmers to agricultural risks and climate change in Madagascar. Philos. Trans. R. Soc. B Biol. Sci. 2014, 369. [CrossRef] [PubMed]

8. Howden, S.M.; Soussana, J.-F.; Tubiello, F.N.; Chhetri, N.; Dunlop, M.; Meinke, H. Adapting agriculture to climate change. Proc. Natl. Acad. Sci. USA 2007, 104, 19691-19696. [CrossRef] [PubMed]

9. Steiner, J.L.; Briske, D.D.; Brown, D.P.; Rottler, C.M. Vulnerability of Southern Plains agriculture to climate change. Clim. Chang. 2018, 146, 201-218. [CrossRef]

10. Wilk, J.; Hjerpe, M.; Yang, W.; Fan, H. Farm-scale adaptation under extreme climate and rapid economic transition. Environ. Dev. Sustain. 2015, 17, 393-407. [CrossRef]

11. Taylor, R.G.; Scanlon, B.; Döll, P.; Rodell, M.; Beek, R.; van Wada, Y.; Longuevergne, L.; Leblanc, M.; Famiglietti, J.S.; Edmunds, M.; et al. Ground water and climate change. Nat. Clim. Chang. 2012, 3, 322-329. [CrossRef] 
12. Wilbanks, T.J.; Kates, R.W. Beyond Adapting to Climate Change: Embedding Adaptation in Responses to Multiple Threats and Stresses. Ann. Assoc. Am. Geogr. 2010, 100, 719-728. [CrossRef]

13. Leichenko, R.; O’Brien, K. Environmental Change and Globalization: Double Exposures; Oxford University Press: Oxford, UK, 2008.

14. Burton, R.J.F.; Peoples, S. Market liberalisation and drought in New Zealand: A case of 'double exposure' for dryland sheep farmers? J. Rural Stud. 2014, 33, 82-94. [CrossRef]

15. Adger, W.N.; Dessai, S.; Goulden, M.; Hulme, M.; Lorenzoni, I.; Nelson, D.R.; Naess, L.O.; Wolf, J.; Wreford, A. Are there social limits to adaptation to climate change? Clim. Chang. 2009, 93, 335-354. [CrossRef]

16. Berrang-Ford, L.; Ford, J.D.; Paterson, J. Are we adapting to climate change? Glob. Environ. Chang. 2011, 21, 25-33. [CrossRef]

17. Grothmann, T.; Patt, A. Adaptive capacity and human cognition: The process of individual adaptation to climate change. Glob. Environ. Chang. 2005, 15, 199-213. [CrossRef]

18. Burke, M.; Emerick, K. Adaptation to Climate Change: Evidence from US Agriculture. Am. Econ. J. Econ. Policy 2016, 8, 106-140. [CrossRef]

19. Olesen, J.E.; Bindi, M. Consequences of climate change for European agricultural productivity, land use and policy. Eur. J. Agron. 2002, 16, 239-262. [CrossRef]

20. Niles, M.T.; Lubell, M.; Brown, M. How limiting factors drive agricultural adaptation to climate change. Agric. Ecosyst. Environ. 2015, 200, 178-185. [CrossRef]

21. Arbuckle, J.G., Jr.; Morton, L.W.; Hobbs, J. Understanding Farmer Perspectives on Climate Change Adaptation and Mitigation: The Roles of Trust in Sources of Climate Information, Climate Change Beliefs, and Perceived Risk. Environ. Behav. 2015, 47, 205-234. [CrossRef] [PubMed]

22. Stewart, A.E. Psychological perspectives on adaptation to weather and climate. In Biometeorology for Adaptation to Climate Variability and Change; Ebi, K.L., Burton, I., McGregor, G.R., Eds.; Springer: Dordrecht, The Netherlands, 2009; pp. 211-232.

23. Osberghaus, D.; Finkel, E.; Pohl, M. Individual Adaptation to Climate Change: The Role of Information and Perceived Risk. ZEW Discussion Paper. 2010. Available online: / ftp.zew.de/pub/zew-docs/dp/dp10061. pdf (accessed on 4 April 2018).

24. Cismaru, M.; Cismaru, R.; Ono, T.; Nelson, K. "Act on Climate Change": An Application of Protection Motivation Theory. Soc. Mark. Q. 2011, 17, 62-84. [CrossRef]

25. Koerth, J.; Vafeidis, A.T.; Hinkel, J. Household-Level Coastal Adaptation and Its Drivers: A Systematic Case Study Review. Risk Anal. 2016, 37, 629-646. [CrossRef] [PubMed]

26. Rogers, R.W. Cognitive and physiological processes in fear appeals and attitude change: A revised theory of protection motivation. In Social Psychophysiology; John, T., Cacioppo, J.T., Petty, R.E., Eds.; Guilford Press: New York, NY, USA, 1983; pp. 153-177.

27. Gaines, B.J.; Kuklinski, J.H.; Quirk, P.J. The logic of the survey experiment re-examined. Political Anal. 2006, 15, 1-20. [CrossRef]

28. Bolsen, T.; Druckman, J.N.; Cook, F.L. How Frames can undermine support for scientific adaptations. Politicization and the status-quo bias. Public Opin. Q. 2014, 78, 1-26. [CrossRef]

29. Nisbet, M.C.; Scheufele, D.A. What's next for science communication? Promising directions and lingering distractions. Am. J. Bot. 2009, 96, 1767-1778. [CrossRef] [PubMed]

30. Lakoff, G. Book Review: As Advertised: A review of the MIT encyclopedia of the Cognitive Sciences. Artif. Intell. 2001, 130, 195-209. [CrossRef]

31. Lakoff, G. Don't Think of an Elephant! Know your Values and Frame the Debate; Chelsea Green Publishing: White River Junction, VT, USA, 2004.

32. Sniderman, P.M. The Logic and Design of the Survey Experiment. An Autobiography of a Methodological Innovation. In Cambridge Handbook of Experimental Political Science; Druckman, J.N., Green, D.P., Kuklinski, J.H., Lupia, A., Eds.; Cambridge University Press: Cambridge, UK, 2011; pp. 102-114.

33. Morton, R.B.; Williams, K.C. Experimental Political Science and the Study of Causality. From Nature to the Lab; Cambridge University Press: Cambridge, UK, 2010.

34. Schwartz, S.H. Normative influences on altruism. In Advances in Experimental Social Psychology; Berkowitzm, L., Ed.; Academic Press: New York, NY, USA, 1977; pp. 221-279.

35. Stern, P.C. Toward a coherent theory of environmentally significant behaviour. J. Soc. Issues 2000, 56, 407-424. [CrossRef] 
36. Stern, N. The Economics of Climate Change: The Stern Review; Cambridge University Press: Cambridge, UK, 2006.

37. Dobson, A. Citizens, Citizenship and governance for sustainability. In Governing Sustainability; Adger, N.W., Jordan, A., Eds.; Cambridge University Press: Cambridge, UK, 2009; pp. 125-141.

38. Steg, L.; Vlek, C. Encouraging pro-environmental behavior: An integrative review and research agenda. J. Environ. Psychol. 2009, 29, 309-317. [CrossRef]

39. Bain, P.; Hornsey, M.J.; Bongiorno, R.; Jeffries, C. Promoting pro-environmental action in climate change deniers. Nat. Clim. Chang. 2012, 2, 600-603. [CrossRef]

40. Sunstein, C.R.; Reisch, L.A. Automatically Green: Behavioral Economics and Environmental Protection. Harv. Environ. Law Rev. 2014, 38, 127-158. [CrossRef]

41. Kachi, A.; Bernauer, T.; Gampfer, R. Climate policy in hard times: Are the pessimists right? Ecol. Econ. 2015, 114, 227-241. [CrossRef]

42. Floyd, D.L.; Prentice-Dunn, S.; Rogers, R.W. A meta-analysis of research on Protection Motivation Theory. J. Appl. Soc. Psychol. 2000, 30, 407-429. [CrossRef]

43. Ostrom, E. A Behavioral Approach to the Rational Choice Theory of Collective Action: Presidential Address, American Political Science Association, 1997. Am. Political Sci. Rev. 1998, 92, 1-22. [CrossRef]

44. Ariely, D. Pedictably Irrational. The Hidden Forces That Shape our Decisions; Harper: New York, NY, USA, 2009.

45. Kohn, A. Why incentive plans cannot work. Harv. Bus. Rev. 1993, 71, 42-43.

46. Boeckmann, M.; Zeeb, H. Using a social justice and health framework to assess European climate change adaptation strategies. Int. J. Environ. Res. Public Health 2014, 11, 12389-12411. [CrossRef] [PubMed]

47. Patt, A. Transforming Energy: Solving Climate Change with Technology Policy; Cambridge University Press: Cambridge, UK, 2015.

48. Pahl-Wostl, C. Towards sustainability in the water sector-The importance of human actors and processes of social learning. Aquat. Sci. 2002, 64, 394-411. [CrossRef]

49. De Rosario Martinez, H. Analysing Interactions of Fitted Models. 2015. Available online: https://cran.rproject.org/web/packages/phia/vignettes/phia.pdf (accessed on 31 May 2017).

50. McDermott, R. Internal and External Validity. In Cambridge Handbook of Experimental Political Science; Druckman, J.N., Green, D.P., Kuklinski, J.H., Lupia, A., Eds.; Cambridge University Press: Cambridge, UK, 2011; pp. 27-40.

51. Mullinix, K.J.; Leber, T.J.; Druckman, J.N.; Freese, J. The Generalizability of Survey Experiments. J. Exp. Political Sci. 2015, 2, 109-139. [CrossRef]

52. Hulme, M. Can Science Fix Climate Change? A Case against Climate Engineering; Polity Press: Cambridge, UK, 2014.

53. Dowd, A.-M.; Marshall, N.; Fleming, A.; Jakku, E.; Gaillard, E.; Howden, M. The role of networks in transforming Australian agriculture. Nat. Clim. Chang. 2014, 4, 558-563. [CrossRef]

54. Buizer, J.; Jacobs, K.; Cash, D. Making short-term climate forecasts useful: Linking science and action. Proc. Natl. Acad. Sci. USA 2016, 113, 4597-4602. [CrossRef] [PubMed]

(C) 2018 by the authors. Licensee MDPI, Basel, Switzerland. This article is an open access article distributed under the terms and conditions of the Creative Commons Attribution (CC BY) license (http://creativecommons.org/licenses/by/4.0/). 